\title{
Awareness regarding Myocardial Infarction among Diabetic Patients Attending in a Tertiary Level Hospital
}

\author{
Rachana Karki KC ${ }^{\mathbf{1}}$ and Apsara Pandey ${ }^{2 *}$ \\ ${ }^{1}$ Register Nurse, Grande International Hospital, Kathmandu, Nepal \\ ${ }^{2}$ Lecturer, Maharajgunj Nursing Campus, Institute of Medicine, Tribhuvan University, Kathmandu, Nepal \\ *Corresponding Author: Apsara Pandey, Lecturer, Maharajgunj Nursing Campus, Institute of Medicine, Tribhuvan University, \\ Kathmandu, Nepal.
}

Received: June 11, 2019; Published: July 18, 2019

DOI: 10.31080 /ASMS.2019.03.0359

\begin{abstract}
Objective: Diabetes has been associated with an increased risk of cardiovascular disease. Mortality and morbidity due to myocardial infarction (MI) is increasing day by day among diabetic patients. The objective of this study was to find out the awareness on myocardial infarction among diabetic patients attending in a tertiary level Hospital.

Methods: A descriptive cross sectional design was used for this study. Altogether 100 diabetic patients were selected using nonprobability purposive sampling technique. Data were collected by using structure interview schedule. Data were analyzed on the basis of research objectives and research questions through SPSS version 16.0. Data were interpreted by using descriptive statistics. Chi square test was calculated to measure association between awareness level and selected socio- demographic characteristics at 95.0\% confident level.

Results: More than half (54.0\%) of respondents were from the age group of 40-59 years, mean age was 55.3 (SD \pm 10.6 ) years and $52.0 \%$ were female. Only $97.0 \%$ respondents had heard about the myocardial infarction and only $55.7 \%$ of respondents had adequate level of awareness. The mean score was $39.0(\mathrm{SD} \pm 6.86)$. Near about one third of respondents $(32.9 \%)$ had awareness on meaning of myocardial infarction as death of heart muscle. Most of the respondents (91.1\%) were aware on risk factors of MI i.e. high blood pressure (BP) and obesity followed by stress (88.6\%), and diabetes mellitus (84.8\%). Almost all respondents were aware on major preventive measures of MI i.e. maintaining healthy weight (97.2\%), consuming low fat and cholesterol diet (94.4\%), avoiding stress (94.4\%) and controlling BP (94.4\%). Awareness level of the respondents was statistically significant with their sex and economic status whereas there was no significant association between age, ethnicity, occupation, education and residence of the respondents. Conclusion: Respondents under the care of diabetes clinic of such tertiary level hospital were not adequately aware about MI. Education and awareness was not sufficient on myocardial infarction among the diabetic patients. Therefore, awareness program on myocardial infarction should be conducted in the hospital and community focusing on group of diabetic patients.

Keywords: Awareness; Myocardial Infarction; Diabetic Patients
\end{abstract}

\section{Introduction}

Cardiovascular diseases (CVDs) are the number one cause of death globally. An estimated 17.7 million people died from CVDs in 2015 , representing $31.0 \%$ of all global deaths. Of these deaths, an estimated 7.4 million were due to coronary heart disease. Over three quarters of CVD deaths take place in low- and middle-income countries World Health Organization (WHO) [1].

In South Asian countries (India, Pakistan, Bangladesh, Sri lanka and Nepal) contribute the highest proportion of the burden of cardiovascular diseases [2].
Coronary heart disease (CHD) is gradually emerging as one of the major health challenge in Nepal. The burden of CHD is increasing in Nepal due to rapid change in life style and urbanization [3].

According to American heart association [4], there is strong correlation between cardiovascular disease (CVD) and diabetes. At least $68.0 \%$ of people age 65 or older with diabetes die from some form of heart disease and $16.0 \%$ die of stroke. Adults with diabetes are two to four times more likely to die from heart disease than adults without diabetes. Diabetes to be one of the seven major controllable risk factors for cardiovascular diseases. Similarly, other several studies demonstrated the function of programmed 
cell death and oxidative stress in pathogenesis of diabetic complications including myocardial infarction [5-8].

Diabetes today is a burning issue among people in developing countries like Nepal due to change in life style and behavioral pattern. Morbidity and mortality due to myocardial infarction is increasing day by day. In India, awareness of diabetes mellitus and its complications among diabetic patients reported that only 50\% diabetic patients are aware of heart attack [9], but no study was to be found in Nepal. Therefore, this study was carried out to find out awareness on myocardial infarction among diabetic patients.

\section{Materials and Method}

A descriptive cross sectional designed study was conducted among 100 type two diabetes patients who were attending endocrinology outpatient department of Tribhuvan University Teaching Hospital, Kathmandu. This tertiary level, referral hospital was established in 1983, where the patients represent from different geographical region, cultural and ethnic group of the country. Sample size was calculated by using formula $\mathrm{z}^{2} \mathrm{pq} / \mathrm{L}^{2}$.

\section{Where,}

Value of " $\mathrm{p}$ " will be taken as $50.0 \%$ that is 0.5 referring the prevalence of India [10].

$\mathrm{q}=$ Proportion in the target population without the characteristics of interest

$\mathrm{q}=1-0.5=0.5$

$\mathrm{L}=$ Allowable error i.e. $10.0 \%=0.1$

Sample size $(\mathrm{n})=\mathrm{z}^{2} \mathrm{pq} / \mathrm{L}^{2}$

$$
\begin{aligned}
& =4 \times 0.5 \times 0.5 / 0.1 \times 0.1 \\
& =1 / 0.01 \\
& =100
\end{aligned}
$$

Therefore, sample size was 100.

Non-probability purposive sampling method was used. Both male and female patients above 30 years old; conscious and well oriented with time, place and person; and diagnosed as type 2 diabetes mellitus by the Endocrinologist at least 6 months before the data collection were included in the study.

Data were collected by using structured interview schedule which was developed by researchers and translated into local (Nepali) language. Pretesting of the instrument was done among $10.0 \%$ of sample size in same setting and excluded in final study. Informed consent was taken from each respondent before collecting data. Ethical approval was taken from Ethical Review Board of Institute of Medicine, Tribhuwan University (IRB, IOM, TU). Data were collected from 17 July 16 August, 2017. Data were analyzed on the basis of research objectives and research questions through SPSS version 16.0. Data were interpreted by using descriptive statistics. Chi square test was calculated to measure association between awareness level and selected socio- demographic characteristics at $95.0 \%$ confident level.

\section{Results}

Socio-demographic Characteristics and Health related Profile

Regarding the socio-demographic characteristics, more than half $(54.0 \%)$ of the respondents belonged to the age group of 40 59 years, mean age was $55.3 y e a r s(S D \pm 10.6$ ), $52.0 \%$ were female and $51.0 \%$ were Brahmin/Chhetri. Similarly, $87.0 \%$ respondents were married, $70.0 \%$ were literate, $32.0 \%$ were house manager

\begin{tabular}{|c|c|}
\hline & $\mathrm{n}=100$ \\
\hline Characteristics & Percent \\
\hline \multicolumn{2}{|l|}{ Age group in completed years } \\
\hline 30-39 & 7.0 \\
\hline $40-59$ & 54.0 \\
\hline 60 above & 39.0 \\
\hline \multicolumn{2}{|l|}{ Mean age: 55.3} \\
\hline \multicolumn{2}{|l|}{ S.D: \pm 10.6} \\
\hline \multicolumn{2}{|l|}{ Sex } \\
\hline Female & 52.0 \\
\hline Male & 48.0 \\
\hline \multicolumn{2}{|l|}{ Marital status } \\
\hline Married & 87.0 \\
\hline Unmarried & 4.0 \\
\hline Widowed & 9.0 \\
\hline \multicolumn{2}{|l|}{ Ethnicity } \\
\hline Brahmin/ Chhetri & 51.0 \\
\hline Janajati & 35.0 \\
\hline Dalit and Madhesi & 14.0 \\
\hline \multicolumn{2}{|l|}{ Education } \\
\hline Can't read and write & 30.0 \\
\hline Can read and write only & 21.0 \\
\hline Primary level & 7.0 \\
\hline Secondary level & 13.0 \\
\hline Higher secondary level & 23.0 \\
\hline Bachelor and above & 6.0 \\
\hline \multicolumn{2}{|l|}{ Occupation } \\
\hline House manager & 32.0 \\
\hline Service & 18.0 \\
\hline Business & 18.0 \\
\hline Agriculture & 23.0 \\
\hline Others* & 9.0 \\
\hline \multicolumn{2}{|l|}{ Address } \\
\hline Outside Kathmandu valley** & 61.0 \\
\hline Inside Kathmandu valley & 39.0 \\
\hline
\end{tabular}
and $61.0 \%$ were from Kathmandu Valley (Table 1).

Table 1: Socio- Demographic Characteristics of the Respondents.

*Others: Social worker, Retired

** Kathmandu valley includes Kathmandu, Bhaktapur, Lalitpur 
Sixty three percent respondents were diagnosed as diabetic mellitus within 6 months to 5 years before data collection. Majority of respondents with diabetes mellitus has hypertension (59.5\%). Only 2.0\% respondents had a past history of MI (Table 2).

Table 2: Health Profile of the Respondents.

\begin{tabular}{|c|c|c|}
\hline & & $\mathrm{n}=100$ \\
\hline Variables & Number & Percent \\
\hline \multicolumn{3}{|l|}{ Duration of diagnosis of diabetes } \\
\hline 6 months -5 years & 63 & 63.0 \\
\hline 6-10 years & 21 & 21.0 \\
\hline $11-15$ years & 10 & 10.0 \\
\hline $16-20$ years & 3 & 3.0 \\
\hline $21-25$ years & 1 & 1.0 \\
\hline 26-30 years & 2 & 2.0 \\
\hline \multicolumn{3}{|l|}{ Co - morbidities $(n=47)$} \\
\hline Hypertension & 28 & 59.5 \\
\hline Hyperthyroidism & 5 & 10.6 \\
\hline Eye problem & 4 & 8.5 \\
\hline Nerve problem & 3 & 6.3 \\
\hline Hypothyroidism & 3 & 6.3 \\
\hline Others* & 4 & 8.5 \\
\hline $\begin{array}{l}\text { History of MI among respondents } \\
(n=100)\end{array}$ & 2 & 2.0 \\
\hline
\end{tabular}

*Others includes knee pain, backache.

\section{Awareness on Myocardial Infraction}

Regarding the awareness on MI, $79.0 \%$ of respondents had heard about it, nearly one third of respondents (32.9\%) gave the right answer that MI is a death of heart muscle and majority of respondents (75.9\%) told that heart is affected in MI. While, concerning about sign and symptoms of MI, 89.5\% of respondents told fainting followed by shortness of breath(88.2\%), dizziness(76.2\%), chest pain(75.0\%), sweating(71.1\%), pain at neck and shoul$\operatorname{der}(47.0 \%)$ as a sign and symptoms of MI (Table 3 ).

Regarding the risk factors of MI, respondents had answered that high BP(91.1\%) followed by obesity (91.1\%), people living with stress (88.6\%), diabetic patient (84.8\%), alcohol consumer (84.8\%), smoker (84.8\%), high blood cholesterol level (77.2\%) and people living with sedentary life style $(73.4 \%)$ are the risk factors of MI. Similarly, $68.4 \%$ of respondents had answered correctly that people of urban area are prone to get MI and $77.2 \%$ of respondents answered that people of above 40 years age groups are more prone to get MI. Concerning the diet, $94.9 \%$ of respondents answered that high intake of meat increases the risk of MI and majority of respondents $(88.6 \%)$ told that red meat are harmful to heart (Table 4).
Table 3: Awareness on Meaning and Signs / Symptoms of Myocardial Infarction

\begin{tabular}{|l|c|c|}
\hline & & $\mathrm{n}=100$ \\
\hline Variables & Number & Percent \\
\hline Heard about myocardial infarction & 79 & 79.0 \\
\hline $\begin{array}{l}\text { Myocardial Infarction is caused by } \\
\text { diabetes }\end{array}$ & 42 & 53.2 \\
\hline $\begin{array}{l}\text { Meaning of myocardial infarction } \\
\text { (n=79) }\end{array}$ & & \\
\hline Death of heart muscle \# & 26 & 32.9 \\
\hline Heart failure & 13 & 16.5 \\
\hline Stroke & 8 & 10.1 \\
\hline Don't know & 32 & 40.5 \\
\hline $\begin{array}{l}\text { Organ affected in myocardial } \\
\text { infarction (n=79) }\end{array}$ & & \\
\hline The heart \# & 60 & 75.9 \\
\hline The brain & 9 & 10.1 \\
\hline The lungs & 2 & 2.5 \\
\hline Don't know & 8 & 10.1 \\
\hline Signs / symptoms of MI & & \\
\hline Fainting \# & 68 & 89.5 \\
\hline Shortness of breath \# & 67 & 88.2 \\
\hline Dizziness \# & 58 & 76.3 \\
\hline Chest pain \# & 54 & 75.0 \\
\hline Sweating \# & & 71.1 \\
\hline Pain at neck and shoulder \# & 47.4 \\
\hline
\end{tabular}

\section{*Multiple responses}

\#Correct responses

Similarly, majority of respondents (91.1\%) gave the correct answer that MI is preventable. Almost all respondents (97.2\%) answered that maintaining healthy weight followed by consuming low fat and cholesterol diet (94.4\%), avoiding stress (94.4\%), controlling BP (94.4\%), controlling diabetes (93.0\%), quitting smoking (93.0\%), quitting alcohol (88.7\%) and performing regular exercise (87.3\%) are the preventive measures of MI. For preventing stress, $86.1 \%$ of respondents answered that ventilation is the most effective measures. Concerning the controlling measures of diabetes, almost all (98.0\%) respondents gave the answer of planned and balanced diet followed by regular exercise (97.5\%), regular intake of medicine (96.2\%) and regular blood sugar checkup (93.7\%) are most effective measures (Table 5).

Relationship between Level of awareness on Myocardial Infarction and Selected Variables

Level of awareness on MI was calculated from median value. Median value was 39 (S.D \pm 6.86$)$. Among the respondents $(n=79)$, $55.7 \%$ had adequate and $44.3 \%$ had inadequate level of awareness on myocardial infarction. 
Table 4: Awareness on Risk factors of Myocardial Infarction.

\begin{tabular}{|c|c|c|}
\hline & & $\mathrm{n}=79$ \\
\hline Variables & Number & Percent \\
\hline \multicolumn{3}{|c|}{ Risk factors of myocardial infarction* } \\
\hline People with blood pressure \# & 72 & 91.1 \\
\hline Obese person \# & 72 & 91.1 \\
\hline People living with stress \# & 70 & 88.6 \\
\hline Diabetic person \# & 67 & 84.8 \\
\hline Alcohol consumer \# & 67 & 84.8 \\
\hline Smoker \# & 67 & 84.8 \\
\hline High blood cholesterol \# & 61 & 77.2 \\
\hline Sedentary life style \# & 58 & 73.4 \\
\hline \multicolumn{3}{|c|}{$\begin{array}{l}\text { Residential risk for myocardial infarc- } \\
\text { tion }\end{array}$} \\
\hline Urban \# & 54 & 68.4 \\
\hline Rural & 8 & 10.1 \\
\hline Both & 14 & 17.7 \\
\hline Don't know & 3 & 3.8 \\
\hline \multicolumn{3}{|c|}{$\begin{array}{l}\text { Age group risk for myocardial infarc- } \\
\text { tion }\end{array}$} \\
\hline Below 5 years & 1 & 1.3 \\
\hline $20-40$ years & 3 & 3.8 \\
\hline Above 40 years \# & 61 & 77.2 \\
\hline Don't know & 14 & 17.7 \\
\hline \multicolumn{3}{|c|}{ Diet risk for myocardial infarction } \\
\hline High intake of meat \# & 75 & 94.9 \\
\hline High intake of cholesterol \# & 72 & 91.1 \\
\hline High intake of sodium \# & 60 & 75.9 \\
\hline \multicolumn{3}{|l|}{ Harmful meat for heart } \\
\hline Red meat \# & 70 & 88.6 \\
\hline Fish & 3 & 3.8 \\
\hline Chicken & 2 & 2.5 \\
\hline Don't know & 1 & 5.1 \\
\hline
\end{tabular}

*Multiple responses

\# correct responses

Similarly, Chi Square was calculated to measure the relationship of level of awareness on MI with selected socio-demographic variables. Respondents' level of awareness was found to be statistically significant with their sex $(\mathrm{p}=0.003)$ (Table 6).

\section{Sources of information}

Respondents had received information about MI from different sources. More than two third (72.2\%) had received information regarding MI from family members, relatives, friends and $69.6 \%$ had received from health workers (Table 7).
Table 5: Awareness on Preventive Measures of Myocardial Infarction

\begin{tabular}{|l|c|c|}
\hline \multicolumn{1}{|c|}{ Variables } & & $\mathrm{n}=79$ \\
\hline Is heart disease preventable & Number & Percent \\
\hline Yes & 72 & \\
\hline No & 7 & 81.1 \\
\hline Preventive measures of MI * (n=72) & & \\
\hline Maintaining healthy weight \# & 69 & 97.2 \\
\hline $\begin{array}{l}\text { Consuming low fat and cholesterol } \\
\text { diet \# }\end{array}$ & 67 & 94.4 \\
\hline Avoiding stress \# & 67 & 94.4 \\
\hline Controlling blood pressure \# & 67 & 94.4 \\
\hline Quitting smoking \# & 66 & 93.0 \\
\hline Controlling diabetes \# & 66 & 93.0 \\
\hline Controlling alcohol \# & 63 & 88.7 \\
\hline Regular exercise \# & 62 & 87.3 \\
\hline $\begin{array}{l}\text { Controlling measures of stress to } \\
\text { prevent MI * }\end{array}$ & & \\
\hline Ventilation \# & 68 & 86.1 \\
\hline Yoga \# & 65 & 82.3 \\
\hline Meditation \# & 60 & 75.9 \\
\hline Worship / prayer \# & 60 & 75.9 \\
\hline Music \# & 55 & 69.6 \\
\hline Others \# & 9 & 11.4 \\
\hline $\begin{array}{l}\text { Controlling measures of diabetes to } \\
\text { prevent MI * }\end{array}$ & & \\
\hline Planned and balanced diet\# & 78 & 98.7 \\
\hline Regular exercise\# & 77 & 97.5 \\
\hline Regular intake of medicine\# & & 96.2 \\
\hline Regular blood sugar check up\# & & 93.7 \\
\hline Insulin administration\# & & 64.6 \\
\hline Others: sitting alone, sleeping & & \\
\hline & & \\
\hline
\end{tabular}

*Multiple responses

\#correct responses

\section{Discussion and Conclusion}

In this study, $79.0 \%$ of respondents had heard about the myocardial Infarction and $21.0 \%$ of respondents had never heard about the term myocardial infarction. Regarding cardiovascular conditions caused by the diabetes, $53.2 .0 \%$ of respondents had answered that diabetes can lead to myocardial infarction. This finding is higher than the findings of study done by [11] in USA, which revealed that $17.0 \%$ of respondents with diabetes were aware that diabetes may cause myocardial infarction. 
Table 6: Relationship between Level of Awareness on Myocardial Infarction and Selected Variables.

\begin{tabular}{|c|c|c|c|}
\hline \multirow[b]{2}{*}{ Variables } & \multicolumn{2}{|c|}{ Awareness level } & \multirow{2}{*}{$\begin{array}{c}\text { p-value } \\
\left(x^{2}\right)\end{array}$} \\
\hline & $\begin{array}{l}\text { Adequate } \\
\text { n (\%) }\end{array}$ & $\begin{array}{c}\text { Inadequate } \\
\text { n (\%) }\end{array}$ & \\
\hline \multicolumn{4}{|l|}{ Age } \\
\hline Below 55 years & $23(56.1)$ & $18(43.9)$ & 0.941 \\
\hline Above 55 years & $21(55.3)$ & $17(44.7)$ & \\
\hline \multicolumn{4}{|l|}{ Sex } \\
\hline Male & $30(71.4)$ & $12(28.6)$ & 0.003 \\
\hline Female & $14(37.8)$ & $23(62.2)$ & \\
\hline \multicolumn{4}{|l|}{ Ethnicity } \\
\hline Janajati/dalit/ madhesi & $19(50.0)$ & $19(50.0)$ & 0.326 \\
\hline Brahmin/ chhetri & $25(61.0)$ & $16(39.0)$ & \\
\hline \multicolumn{4}{|l|}{ Occupation } \\
\hline $\begin{array}{l}\text { Agriculture/ house } \\
\text { manager }\end{array}$ & $19(48.7)$ & $20(51.3)$ & 0.218 \\
\hline Service/business & $25(62.5)$ & $15(37.5)$ & \\
\hline \multicolumn{4}{|l|}{ Education } \\
\hline Literate & $37(57.8)$ & $27(42.2)$ & 0.434 \\
\hline Illiterate & 7 (46.7) & $7(53.3)$ & \\
\hline \multicolumn{4}{|l|}{ Residence } \\
\hline Inside Kathmandu valley & $26(51.0)$ & $25(49.0)$ & 0.255 \\
\hline $\begin{array}{l}\text { Outside Kathmandu } \\
\text { valley }\end{array}$ & $18(64.3)$ & $10(35.7)$ & \\
\hline
\end{tabular}

Chi square test was applied at $5.0 \%$ significance level

Table 7: Sources of Information on Myocardial Infarction.

\begin{tabular}{|l|c|c|}
\hline & & $\mathrm{n}=79$ \\
\hline Sources of information* & Number & Percent \\
\hline Family members/ relatives/ friends & 57 & 72.2 \\
\hline Health workers & 55 & 69.6 \\
\hline Television & 41 & 51.9 \\
\hline Radio & 38 & 48.1 \\
\hline Magazine & 33 & 41.8 \\
\hline Others & 4 & 5.1 \\
\hline Others: Experienced by self, self study & & \\
\hline
\end{tabular}

*multiple responses

Among the various risk factors of MI, almost all (91.1\%) respondents answered high blood pressure as a major risk factor of MI followed by obesity (91.0\%) and diabetes mellitus (88.6\%) in contrast to this study conducted by (Karthik, 2006) in Spain more than half $(55.3 \%)$ of the respondents answered high cholesterol level followed by Hypertension (43\%), family history (42.5\%) with very few patients being aware of DM (14.5\%) and obesity (13.6\%). The variation might be due to variation in setting and study populations
In present study, $88.6 \%$ of respondents told that red meat is harmful for heart, this finding is considerably similar to finding found in the study done by [12] in which $(80.7 \%)$ respondents had given correct answer that red meat is harmful for heart.

In this study, majority of respondents (89.5\%) were aware of fainting as a sign and symptoms of MI followed by, (88.2\%) shortness of breath, (76.2\%) dizziness, (75.0\%) chest pain, $(71.1 \%)$ sweating, (47\%) pain at neck and shoulder are the signs and symptoms of MI. In contrast to these findings study conducted by [13] in Spain revealed that $81.0 \%$ of respondents were aware of chest pain followed by $(43.0 \%)$ tiredness, $(42.0 \%)$ shortness of breath (24.0\%) fainting, (42.0\%) sweating, (35.0\%) pain at neck and shoulder. Present study showed that fainting, shortness of breath, dizziness, chest pain are the more common where as in previous study conducted by [13] in Spain showed that chest pain, shoulder pain/discomfort, shortness of breath, and tiredness were more common during MI in patients with diabetes, and fainting was less common. The variation might be due to variation in setting and study populations.

Regarding the preventive measures of myocardial infarction, almost all the respondents were aware of preventive measures such as $(94.4 \%)$ consuming low fat and cholesterol diet followed by (94.4\%) controlling BP, (94.4\%) quitting smoking. The study done by [11] contradicts the present study in which few people with diabetes could name important methods of preventing the risk of heart attack, such as lowering cholesterol (8.0\%), quitting smoking (7.0\%), reducing blood pressure (5.0\%). The variation might be due to variation in setting and study populations.

Results of this study showed (71.4\%) males were more aware than female $(37.8 \%)$ on myocardial infarction, which is supported by the study conducted by [14] in Pakistan revealed that male $(60.0 \%)$ are more aware than female.

Education seems to play a positive role in increasing the awareness of myocardial infarction, in the present study $57.8 \%$ of respondents had adequate awareness among the literate respondents compared to those who are illiterate $(46.7 \%)$. This finding is supported by the study conducted by [14] in Pakistan in which 75.0\% of respondents had adequate awareness among the respondents who were literate compared to those who are illiterate (27.64\%) [15].

In conclusion, though the diabetic patients are in regular contact with physician still nearly one third of respondents had never heard about myocardial infarction and nearly half of the respondents had inadequate level of awareness on MI. Therefore, awareness program on myocardial infarction should be conducted in the hospital and community focusing on group of diabetic patients. 


\section{Bibliography}

1. World Health Organization. Cardiovascular diseases (2017).

2. Guha S., et al. "Cardiological Society of India: Position statement for the management of ST elevation myocardial infarction in India". Indian Heart Journal 69 (2017): 63-97.

3. Shrestha R and Shrestha S. "Health-related Quality of Life of Patients with Coronary Heart Disease Attending a Cardiac Care Centre in Kathmandu". Journal of Institute of Medicine 37 (2015).

4. American Heart Association. Cardiovascular disease (2017).

5. Tian XF, et al. "Cell death, dysglycemia and myocardial infarction". Biomedical reports 1 (2013): 341-346.

6. Jha C., et al. "A casual link between oxidative stress and inflammation in cardiovascular and renal complication of diabetes". Ortl and Press Limited on behalf of the Biochemical Society 132 (2018): 1811-1836.

7. Hafez YM., et al. "The emerging role of the epigenetic enzyme Sirtuin-1 and high mobility group Box 1 in patients with diabetic foot ulceration". Diabetes and Metabolic Syndrome: Clinical Research and Reviews 12 (2018): 1065-1070.

8. Severino P., et al. "Myocardial Ischemia and Diabetes Mellitus: Role of Oxidative Stress in the Connection between Cardiac Metabolism and Coronary Blood Flow". Journal of Diabetes Research (2019).

9. Durgad A., et al. "Awareness of Diabetes Mellitus and its Complications among Patients at Tertiary Care Hospital". International Journal of Scientific Study 4 (1) 73-82.

10. Dubey L., et al. "Relationship between type 2 diabetes mellitus and coronary artery lesion characteristics". Nepalese Heart Journal 10 (2013): 20-22.

11. Merz NB., et al. "Women's ischemic syndrome evaluation: current status and future research directions: report of the $\mathrm{Na}$ tional Heart, Lung and Blood Institute workshop: October 2-4, 2002: executive summary". Circulation 109 (2014): 805-807.

12. Dahal P and Karki R. Knowledge and practice regarding prevention of myocardial infarction among visitors of Sahid Gangalal national heart center, Kathmandu, Nepal". Diabetes Management 7 (2017): 240-246.

13. Ängerud KH., et al. "The process of care-seeking for myocardial infarction among patients with diabetes". The Journal of Cardiovascular Nursing 30.5 (2015): E1.
14. Ullah F., et al. "Knowledge of diabetic complications in patients with diabetes mellitus". Journal of Ayub Medical College Abbottabad 27 (2015): 360-363.

15. Mozaffarian D., et al. "Heart disease and stroke statistics-2016 update" (2016).

\section{Volume 3 Issue 8 August 2019 \\ (C) All rights are reserved by Rachana Karki $\mathrm{KC}$ and Apsara Pandey.}

